\title{
Afrikkalainen muuttoliike, turvallisuus ja Venäjä
}

Vuosina 2015-2016 Suomeen tuli yli 30000 turvapaikanhakijaa erityisesti Lähi-Idästä ja eri Aasian ja Afrikan maista. Pieni osa heistä tuli niin sanottua arktista reittiä Pohjois-Venäjältä. Heistä neljäsosa oli Venäjällä asuneita maahanmuuttajia. Keskitymme tähän muuttoliikkeeseen Venäjällä asuneiden afrikkalaisten maahanmuuttajien näkökulmasta. Keitä afrikkalaistaustaiset Venäjällä ovat, ja keitä olivat arktisen reitin afrikkalaiset? Syyt maastamuuton ja arktisen reitin taustalla nostavat esiin turvallisuuden moniulotteisuuden kansainvälisissä muuttoliikkeissä. Turvapaikanhakijoiden vaikea asema Venäjällä nivoutui monenlaiseen arjen turvattomuuteen ja rasismiin, määritteli muuttopäätöksiä ja siirtyi myös salakuljettajien avustuksella Suomen Schengen rajalle valtion turvallisuuteen liittyviksi kysymyksiksi rajojen hallinnasta. Tutkimus perustuu arktisen reitin Venäjällä asuneiden afrikkalaisten turvapaikkahakemuspöytäkirjoihin sekä Venäjän afrikkalaisia ja maahanmuuttopolitiikkaa käsittelevään tutkimuskirjallisuuteen.

Joni Virkkunen, Minna

Piipponen \& Tuulia Reponen

Vuoden 2015-2016 "pakolaiskriisin" yhteydessä Suomeen tuli yli 30000 turvapaikanhakijaa erityisesti Lähi-Idästä ja eri Aasian ja Afrikan maista. Suurin osa turvapaikanhakijoista tuli Suomeen lännestä Ruotsin kautta, mutta noin 1750 heistä tuli niin sanottua arktista reittiä Pohjois-Venäjältä. Artikkelimme valottaa tätä Venäjän kautta Suomeen ja Euroopan Unioniin kohdistunutta muuttoliikettä Venäjällä asuneiden afrikkalaisten maahanmuuttajien kertomusten tarkastelulla. Tämä avaa näkökulmia etenkin arktisen reitin käyttöön ja Venäjän asemaan kansainvälisissä muuttoliikkeissä sekä Afrikan maista tulleiden maahanmuuttajien asemaan Venäjällä. ${ }^{1}$

Afrikkalaisten maahanmuuttajien esimerkki nostaa hyvin esille turvallisuuden moniulotteisuuden. Siinä missä mediajulkisuudessa arktisesta reitistä sekä Venäjältä Suomeen ja Europan Unioniin kohdistuvasta muuttoliikkeestä puhutaan usein vain rajojen hallintaan 
liittyvinä haasteina, ilmiön taustalla on monia koti- ja läpikulkumaiden yhteiskunnallisia ja poliittisia tekijöitä sekä liikkujien arkeen liittyvää mm. moniperustaisen syrjinnän aiheuttamaa turvattomuutta. ${ }^{2}$ Kysymys oli siis myös maastamuutosta ja maiden sisäisistä ja ylirajaisista prosesseista kuten epätasa-arvon kokemuksista, viisumi- ja työlupapolitiikasta, työmarkkinoiden toimivuudesta, erilaisesta mediajulkisuudesta ja maantieteellisistä mielikuvista sekä salakuljetusverkostojen ja kansainvälisen rikollisuuden toiminnasta (C.A.S.E 2006, 456-464; Heusala 2012, 103-108). Työn taustalla on ajatus turvallisuuden monikerroksisuudesta (kts. Virkkunen 2018; GLASE 2016) ja siitä, miten ihmisten (tässä tapauksessa afrikkalaisten maahanmuuttajien) arjen turvallisuus tai turvattomuus nivoutuu osaksi valtion turvallisuuteen liittyviä kysymyksiä rajojen hallinnasta, sisäisen turvallisuuden kysymyksistä tai vaikkapa rasismista.

Afrikkalaiset maahanmuuttajat ovat Venäjällä suhteellisen pieni ja hajanainen, mutta näkyvä ryhmä. Arvioiden mukaan Venäjällä on tällä hetkellä noin 40000 Afrikan eri osista tullutta maahanmuuttajaa (Bondarenko 2018; Bondarenko et al. 2014, 211). Heistä näkyvimpiä ovat suurten kaupunkien, kuten Moskovan, metroasemilla mainoksia jakavat maahanmuuttajat. Nämä huonon asemansa kanssa kamppailevat maahanmuuttajat ovat kuitenkin vain osa afrikkalaisista Venäjällä. Neuvostoliitossa koulutuksensa saanut korkeasti koulutettu afrikkalainen diaspora ja liikemiehet sekä lähetystöjen henkilökunta elää Venäjällä hyvin turvattua elämää ja vuorovaikutus edellä mainittujen "uusien" maahanmuuttajaryhmien välillä on vähäistä. (Bondarenko 2018; 2014, 215-217; Boltovskaya 2010.) Tässä artikkelissa keskitymme erityisesti Neuvostoliiton hajoamisen jälkeen Venäjälle saapuneisiin "uusiin" maahanmuuttajiin ja heidän kertomuksiinsa arjen turvattomuudesta. Nostamme keskusteluun kaksi tutkimusmateriaalissamme selvästi esiin nousevaa teemaa, järjestäytyneen rikollisuuden ja ihmiskaupan sekä seksuaalivähemmistöjen aseman. Kansainvälinen rikollisuus ja ihmissalakuljetus mahdollistavat turvapaikanhakijoiden liikkumisen nyky-Euroopassa. Samalla se asettaa useat ihmisryhmät, kuten naiset, lapset ja heikosti koulutetut, erityisen haavoittuviksi erilaiselle matkan aikana tapahtuvalle hyväksikäytölle.

Tutkimuksemme perustuu vuosina 2015-2016 arktisen reitin kautta Suomeen tulleiden ja Venäjällä ennen sitä asuneiden afrikkalaisten turvapaikkakuulustelu- ja puhuttelupöytäkirjoihin. Lisäksi käytämme afrikkalaista mahanmuuttoa Venäjälle sekä Venäjän maahanmuuttopolitiikkaa ja maahanmuuttajien asemaa käsittelevää tutkimuskirjallisuutta. Pöytäkirjaaineistossa turvapaikanhakijoiden kertomukset käsittelevät kiinnostavasti nyky-Venäjää ja Venäjän maastamuuton taustalla olevia ilmiöitä: syvää eriarvoisuutta, maahanmuuttajien perus- ja ihmisoikeuksiin liittyviä ongelmia, maahanmuuttajien halua parantaa omaa elämää sekä erilaisia ulkomaalaisista hyötymään pyrkiviä tahoja, kuten korruptoituneita poliiseja ja ihmissalakuljetusverkostoja. Kertomuksia analysoimalla pyrimme ymmärtämään paremmin muuttoliikkeen ja turvallisuuden yhteyttä ja arktisen reitin monitahoisuutta. Keitä olivat Venäjältä Suomeen tulleet afrikkalaiset? Mitä merkityksiä turvallisuus tai turvattomuus saivat afrikkalaisten turvapaikanhakijoiden kertomuksissa Venäjästä ja muuttoliikkeestä? Mitä nämä kertomukset turvallisuudesta tai turvattomuudesta kertovat Venäjästä maahanmuuttomaana?

\section{Afrikkalaiset Venäjällä}

Afrikkalaisen Venäjän historia on pidempi kuin usein ajatellaan. Venäjällä ei ole samanlaista kolonialistista historiaa kuin monissa länsimaissa. (Bondarenko et. al. 2014, 208.) Ensimmäiset afrikkalaiset, tai afrikkalaista alkuperää olevat henkilöt, saapuivat maahan jo 
Venäjän keisarikunnan aikaan 1600- ja 1700-luvuilla. Ulkomaankaupan yleistyessä maahan saapui eurooppalaisten tai amerikkalaisten kauppalaivojen mukana yksittäisiä afrikkalaista alkuperää olevia merimiehiä. Tummaihoiset adoptiolapset ja eksoottisten palvelijoiden pitäminen turbaaneissaan ikään kuin koristeina olivat yläluokan statussymboleita. (Blakely 2007, 37-45.) Yksi tunnetuimmista tummaihoisista maan historiassa on kirjailija Aleksandr Puškinin etiopialaissyntyinen isoisä Ibrahim Gannibal. Hänet adoptoitiin Konstantinopolin kautta Pietari Suuren hoviin vuonna 1704. (Blakely 2007, 39; Cocks 2007.) Nykypäivän afrikkalaisen muuttoliikkeen ja diasporan näkökulmasta tärkeämmät ajanjaksot sijoittuvat kuitenkin Neuvostoliiton alkuaikojen teollistumisen ja erityisesti 1950-1980-lukujen ideologisen propagandan aikaan sekä Neuvostoliiton jälkeiseen muuttoliikkeeseen.

Ensimmäinen suuri ryhmä afrikkalaisia saapui Neuvostoliittoon vuonna 1957 Moskovassa järjestetyille kuudensille kansainvälisille nuorisofestivaaleille. Festivaali järjestettiin osana kulttuuridiplomatiaa sekä Neuvostoliiton pyrkimystä edistää yhteyksiä ulkomaailman kanssa ja mahdollisuuksia kansainvälisiin kontakteihin tilanteessa, jossa maa oli avautumassa stalinistisesta sulkeutuneisuudesta (Koivunen 2014, 88; Matusevich 2012). Festivaalin aikana afrikkalaiset delegaatiot nauttivat laajasta huomiosta ja heidän hotelleista tulikin Moskovan "rakkauden kesän" kohtaamispaikkoja, jossa paikallisilla nuorilla oli mahdollista tutustua lähemmin "eksoottisiin" vieraisiin etelästä (Matusevich 2012, 333; 2009, 21). ${ }^{3}$

Moskovassa sijaitseva Patrice Lumumba -yliopisto on yksi tunnetuimmista kansainvälisen koulutuksen keskuksista Venäjällä ja koko maailmassa. ${ }^{4}$ Se perustettiin vuonna 1960 post-koloniaalisessa maailmanpoliittisessa tilanteessa, jossa koulutuksella oli erityinen rooli modernisaation ja kehityksen toteutumisessa (Katsakioris 2017). Želtov $(2012,4)$ arvioi, että jo vuoteen 1980 mennessä jopa 100000 afrikkalaista oli saanut koulutuksensa Neuvostoliitossa, mukaan lukien 700 tieteiden kandidaattia ja tohtoria. Quist-Adade $(2007,155)$ puolestaan muistuttaa, että vuosina 1955-1978 noin 10000 afrikkalaista (etenkin Somaliasta, Tansaniasta ja Etiopiasta) oli saanut sotilaallisen koulutuksen Neuvostoliitosta. Nämä Neuvostoliitossa koulutuksensa saaneet ja maahan valmistumisen jälkeen jääneet muodostavat hajanaisen, mutta verrattain hyvin toimeentulevan "arvostetun" afrikkalaisen diasporan. Jo opiskeluaikana heidän kielitaidosta ja integraatiota huolehti yleisen sosiaalisen kanssakäymisen lisäksi yliopistojen tätä varten palkattu henkilökunta kuten psykologit. (Bondarenko et. al. 2014, 213). Koulutus, hyvä kielitaito ja (usein avioliiton kautta saatu) Venäjän kansalaisuus tukevat monien afrikkalaisten liikemiesten, toimittajien, yliopisto-opettajien, lääkärien, muusikoiden ja taiteilijoiden asemaa.

Neuvostoliiton hajottua kansainvälinen opiskelijavaihto hiipui, korkeakouluopinnot muuttuivat maksullisiksi ja sekä afrikkalaisten opiskelijoiden että maassa asuvien maahanmuuttajien määrä laski merkittävästi. Samalla kuitenkin maan rajat avautuivat matkailulle ja lyhyiden turisti- ja liikemiesviisumien saanti helpottui. Mahdollisuutta ovat hyödyntäneet erityisesti eri Afrikan maiden konfliktialueilta maahan saapuneet pakolaiset ja turvapaikanhakijat sekä elämäänsä uusia mahdollisuuksia hakevat taloudelliset siirtolaiset. Nämä vähän koulutetut ja heikosti venäjän kieltä osaavat "tavalliset maahanmuuttajat" muodostavat toisen, varsin erilaisen ryhmän maahan hyvin integroituneen keskiluokkaisen afrikkalaisen diasporan rinnalle. (Bondarenko et al. 2014, 215.) Heillä on selvästi heikommat sosiaaliset ja taloudelliset edellytykset oleskella ja selvitä maassa ilman ongelmia. Laajempien sosiaalisten verkostojen ja muuta maata parempien työllistymismahdollisuuksien takia he ovat keskittyneet aiempaa enemmän suuriin kaupunkeihin kuten Moskovaan ja Pietariin. 
Usein maaseudulta lähteneet heikosti koulutetut ja sotaa, vainoa, painostusta tai hyväksikäyttöä pakenevat kärsivät työttömyydestä, asumiseen, oleskelulupiin ja rekisteröitymiseen liittyvistä ongelmista, rasismista ja korruptiosta viranomaisten toiminnassa (erityisesti poliisi). He ovat erittäin huonosti tietoisia oikeuksistaan ja velvollisuuksistaan, ja joutuvat helposti viranomaisten, työnantajien ja maahanmuuttajien auttajina esiintyvien salakuljettajien harhauttamiksi. Moni heistä on maassa paperittomana ilman oleskelu- ja työlupaa sekä asuinpaikan rekisteröintiä ${ }^{5}$, usein tipahdettuaan tähän asemaan oltuaan maassa jonkun aikaa laillisesti. Arvioiden mukaan suurin osa, ehkä jopa $90 \%$, näistä uusista afrikkalaisista pitää Venäjää välietappina matkalla Eurooppaan (Bondarenko 2018; Bondarenko et. al. 2014, 2012; Ivakhniouk 2004). Venäjän vuoden 2018 jalkapallon maailmanmestaruuskisojen yhteydessä myös monet afrikkalaiset "jalkapallofanit" hyödynsivät kisoihin kehitettyä kisapassia ja viisumivapautta päästäkseen Venäjälle ja edelleen Euroopan Unioniin (Ekholm 2018; Kunichoff 2018a; Kunichoff 2018b; Paananen 2018; TASS 2019).

Yksi suurimmista maahanmuuttajien arkeen ja turvallisuuteen Venäjällä vaikuttava kysymys on selvästi muukalaisvihamielinen ilmapiiri ja monella tavalla esiin nouseva rasismi. Bondarenkon et. al. mukaan $(2014,209)$ 1980-luvulle saakka mielikuva afrikkalaisista oli Venäjällä yleisesti ottaen positiivinen. Se viittasi imperialismia ja köyhyyttä vastustaviin aktivisteihin. Gorbatšovin perestroikan alettua mielikuva on muuttunut negatiiviseksi. Heidät nähdään joko tyhminä ja epätoivoisina petoina, joiden auttamiseen järjestelmä haaskasi rahaa, tai eksoottisina objekteina ja mielenkiinnon kohteina, joille ei ole paikkaa venäläisessä kaupunkitilassa. Seuraava esimerkki arktisen reitin kautta tulleen kolmekymppisen afrikkalaisen miehen kertomuksesta osoittaa hyvin venäläisten stereotypioihin ja arjen rasismiin liittyvän turhautumisen: "Olimme kuin klovnit rannalla, nostelimme lapsia ja tanssimme" (kongolainen mies, rivi 1049).

\section{Arktinen reitti ja afrikkalaiset}

Arktinen reitti Norjan ja Venäjän sekä Suomen ja Venäjän välisen Schengenin ulkorajan kautta oli uusi ilmiö osana laajempaa, Lähi-Idästä, Aasiasta ja Afrikasta Eurooppaan suuntautunutta epäsäännöllistä muuttoliikettä (Nerg \& Järvenkylä 2019). Matkat Suomeen kulkivat useimmiten lentäen Moskovan ja osittain Pietarinkin kautta Pohjois-Venäjälle Murmanskiin, Kantalahteen ja Alakurttiin. Sieltä ne jatkuivat muutaman päivän tai jopa muutaman viikon odottelun jälkeen kohti Suomen Raja-Joosepin ja Sallan raja-asemia.

Turvapaikanhakijoita saapui Suomeen pitkin syksyä 2015, etenkin sen jälkeen, kun Norja ja Venäjä sopivat marraskuussa 2015, ettei Venäjä päästä enää turvapaikanhakijoita Norjaan Storskogin raja-aseman kautta ilman Schengen-viisumia (Moe \& Rowe 2016; Rajavartiolaitos 2016a). Suomeen liikenne loppui helmikuun lopussa 2016 (Rajavartiolaitos 2016b). Arktista reittiä pitkin Suomeen tuli Venäjän läpi suhteellisen suoraan matkustaneita turvapaikanhakijoita, jotka käyttivät Venäjää transit- eli läpikulkumaana ja Venäjällä aiemmin asuneita maahanmuuttajia, jotka päättivät lähteä Venäjältä tässä tilanteessa. Turvapaikanhakijoiden kuulustelu- ja puhuttelupöytäkirjojen ${ }^{6}$ (myöhemmin turvapaikkahakemukset) kertomukset ilmentävät Eurooppaan suuntautuvien muuttoliikkeiden monimuotoisuutta ja pirstoutuneisuutta (Crawley et al. 2018). Erilaiset ihmisryhmät olivat liikkeellä samaan aikaan. Samoin turvapaikanhakijoiden syyt lähteä Venäjälle ja edelleen Eurooppaan olivat moninaiset, mm. työ, turvapaikka, opiskelu sekä perhe. Erilaiset syyt myös limittyivät toisiinsa ja koska matka voi olla pitkäkin, sen taustalla olevat syyt voivat vaihtua, kun elämä tai maailma ympärillä muuttui. 
Arktista reittiä Suomeen tulleet turvapaikanhakijat edustivat kaikkiaan yli kolmeakymmentä lähtömaata tai kansalaisuutta. Kaiken kaikkiaan arktista reittiä pitkin Suomeen saapui 1164 turvapaikanhakijaa. Afrikkalaiset ovat afganistanilaisten ohella suurin ryhmä, joka on asunut Venäjällä ennen Suomeen tuloa (Piipponen \& Virkkunen 2019). Tässä artikkelissa tarkastelemme Afrikan maista arktisen reitin kautta syyskuun alun 2015 ja helmikuun lopun 2016 välillä Suomeen tulleita turvapaikanhakijoita (yhteensä 202) ja erityisesti heitä, jotka olivat asuneet Venäjällä ennen Suomeen tuloaan. Empiirinen aineistomme koostuu näiden henkilöiden 117 turvapaikkahakemuksesta. Kuten Taulukko 1 osoittaa, nämä olivat yli puolet kaikista Afrikan maista lähtöisin olevista arktisen reitin turvapaikkahakemuksista.

Taulukko 1. Arktisen reitin kautta Suomeen tulleiden afrikkalaisten turvapaikkahakemukset vuosina 2015-2016, turvapaikkahakemusten lukumäärät.

\begin{tabular}{|c|c|c|c|}
\hline Lähtömaa & $\begin{array}{c}\text { Venäjällä asu- } \\
\text { neet }\end{array}$ & $\begin{array}{c}\text { Venäjää läpi- } \\
\text { kulkumaana } \\
\text { käyttäneet }\end{array}$ & Yhteensä \\
\hline Kamerun & 42 & 12 & 54 \\
\hline Marokko & 3 & 25 & 28 \\
\hline Kongon demokraattinen tasavalta & 15 & 7 & 22 \\
\hline Nigeria & 19 & 1 & 20 \\
\hline Sudan & 10 & 6 & 16 \\
\hline Gambia & 9 & 3 & 12 \\
\hline Guinea & 6 & 6 & 12 \\
\hline Norsunluurannikko & 5 & 5 & 10 \\
\hline Muut & 8 & 20 & 28 \\
\hline Yhteensä & 117 & 85 & 202 \\
\hline
\end{tabular}

Venäjällä asuneet afrikkalaiset turvapaikanhakijat olivat kotoisin lähinnä Saharan alueelta ja sen eteläpuoleisesta Afrikasta. He tulivat kaikkiaan kolmestatoista eri maasta, mutta valtaosin Kamerunista, Nigeriasta, Kongon demokraattisesta tasavallasta ja Sudanista ( 86 hakemusta). Valtaosa heistä tuli yksin ja suurin osa oli miehiä (77). Naiset (40) olivat valtaosin lähtöisin Nigeriasta, Kamerunista ja Kongon demokraattisesta tasavallasta. Sekä miesten että naisten keski-ikä oli 29-30 vuotta. Arktisen reitin afrikkalaiset kuuluivat Venäjällä "uusien" afrikkalaisten maahanmuuttajien ryhmään ja asuivat lähinnä suurissa kaupungeissa, kuten Moskova ja Pietari. Venäjällä oli asuttu ennen lähtöä Suomeen keskimäärin 2-3 vuotta, mutta tämä aika vaihteli muutamasta kuukaudesta yli kymmeneen vuoteen. Venäjällä asumisen määrittelimme turvapaikanhakijan kertomuksesta ilmenevän kokonaistilanteen mukaan. Maassa vietetyn ajanjakson lisäksi kertomukset kotimaasta lähdön syistä, syistä lähteä Venäjälle, työn, viisumin, asumisluvan ja turvapaikan hakemisesta ja asumisesta maassa sekä syistä lähteä Venäjältä erottivat Venäjällä asuneet maata vain transit-reittinä käyttäneistä.

Afrikasta käsin katsottuna Venäjä näyttäytyy mahdollisena pakomaana ja osana Eurooppaa, paikkana ratkaista tulevaisuuteen ja turvattomuuteen liittyviä ongelmia. Samalla Afrikan mais- 
ta on vaikea saada viisumia EU-ja Schengen-maihin. Venäjän 1990-luvulta alkaen vapautunut viisumipolitiikka, viranomaisten korruptio ja yhteydet kansainväliseen rikollisuuteen, sekä internetin ja sosiaalisen median kautta nopeasti liikkuva tieto, nousivat selvästi esiin arktisen reitin aineistossamme. Venäjälle lähdettiin yleensä opiskelija- tai turistiviisumilla, Suomeen tai Schengen alueelle turvapaikanhakijoilla viisumia ei ollut. Viidesosa Venäjälle muuttaneista kertoi kuitenkin aiemmin hakeneensa viisumia Ranskaan, Alankomaihin, Viroon, Italiaan, Liettuaan, Saksaan, Suomeen, Itävaltaan, Puolaan tai Unkariin.

Käsittelemme hakemuspöytäkirjoja Pattersonia ja Monroeta $(1998,330)$ mukaillen eräänlaisina kertomuksina, joissa myös hakijat jäsentävät päätöksiään, liikkeitään ja kokemuksiaan sekä tulkitsevat niitä sosiaalisissa ja kulttuurisissa yhteyksissään. Samalla ymmärrämme yhdeksi aineistoa rajoittavaksi yhteydeksi sen tilanteen, jossa kertomukset on tuotettu. Niiden pyrkimys on vakuuttaa viranomaiset turvapaikkahakemuksen uskottavuudesta (Puumala, Ristimäki \& Ylikomi 2019; Holland 2018). Turvapaikkahakemuksessa valtion ja kansainvälisen oikeuden turvapaikkaperusteet kohtaavat hakijoiden kokemukset turvallisuudesta. Hakemus muodostuu institutionaalisessa vuorovaikutuksessa, jota ohjaa ja rajoittaa sen tarkoitus. Lisäksi sitä luonnehtii viranomaisen ja haastateltavan oikeuksien ja velvollisuuksien sekä tiedollisten ja taidollisten resurssien asymmetrisyys (Tanttu 2017).

Käytännössä kertomuksissa näkyy näiden tilanteiden ongelmallisuus, myös kielivaikeudet, eri kertojien aiheuttamana epäyhtenäisyytenä. Haastattelut hakemukseen tehdään turvapaikanhakijan äidinkielellä ja tulkin välityksellä. Osittain hakijoiden kertomukset on kirjoitettu pöytäkirjoissa sanasta sanaan tulkin käännöksen mukaan hakijan vastauksista ja osittain haastatelleen viranomaisen sanoin. Tämä näkyy myös artikkelimme analyysiosassa siten, että käyttämissämme sitaateissa suora ja epäsuora kerronta vaihtelee, välillä tarinaa kerrotaan suoraan turvapaikanhakijan, välillä tulkin ja/tai viranomaisen näkökulmasta. Aineiston haasteellisuudesta ja rajoituksista huolimatta kertomusten muoto sekä laaja aineisto auttavat meitä järjestämään turvapaikanhakijoiden käsityksiä Venäjästä, elämästään Venäjällä, matkastaan, asemastaan ja turvallisuudestaan. Tässä artikkelissa emme tarkastele turvapaikanhakijoiden motiiveja tai yksittäisten kertomusten todenperäisyyttä, eivätkä päätökset tai mahdolliset jatkohakemukset kuulu tutkimusmateriaaliin.

Pöytäkirja-aineiston kuulusteluosio perustuu standardilomakkeeseen ja puhutteluosio litteroituun tapauskohtaiseen haastatteluun. Luimme turvapaikkahakemukset maahanmuuttoviraston tiloissa ja teimme laadulliset ja numeeriset muistiinpanot taulukkomuotoon myöhempää analyysia varten. Artikkelin lainauksissa pöytäkirja-aineistosta viitataan hakijakohtaisiin tapauksiin taulukkoaineistomme rivinumeroilla. Laajan aineiston laadullinen sisällön analyysi kohdistuu erityisesti kertomuksista nouseviin näkökulmiin turvallisuudesta (Tuomi \& Sarajärvi 2018). Keskeisempänä kysymyksenä materiaalista nousi esiin turvapaikanhakijoiden arjen turvattomuus.

\section{Arjen turvattomuus Venäjällä}

John Round ja Irina Kuznetsova (2016) arvioivat, että maahanmuuttajien on Venäjällä erittäin vaikeaa toimia täysin virallisten normien mukaisesti käytännössä. Tämä erityisesti siksi, että oleskelun, asumisen ja työnteon viranomaiskäytännöt, byrokratiaviidakko ja harmaan talouden logiikka jättävät työn- ja vuokranantajille paljon tilaa mahdolliselle hyväksikäytölle (Reeves 2013). Samalla turvapaikka- ja maahanmuuttopolitiikan kiristykset, lisääntyneet maahantulokiellot, karkotukset ja pidätykset ovat koskettaneet maahanmuuttajia yhä useammin 
(Ryazantsev 2016). Ihmisoikeusjärjestö Civic Assistance Committeen neuvonantaja Varvara Tretyak kiteyttää tilanteen lehtihaastattelussa (Kunichoff 2018b): "Heidän mahdollisuutensa turvapaikkaan Venäjällä ovat erittäin pienet, lähellä nollaa. [...] Heillä ei ole muuta mahdollisuutta, kun jäädä Venäjälle ja yrittää hakea”.

Viime vuosina Venäjälle tulleiden afrikkalaisten pakolaisten ja taloudellisten siirtolaisten koulutus ja kielitaito, tieto Venäjästä ja maailmasta sekä sosiaaliset maahanmuuttoon ja integraatioon liittyvät voimavarat ovat vähäiset (Bondarenko 2018; 2014). Maahanmuuttajien kokema arjen turvattomuus Venäjällä on laaja-alaista ja voidaan sanoa, että monet venäläisen yhteiskunnan tämänhetkiset ongelmat kasaantuvat nimenomaan maahanmuuttajien arjessa. Seuraavassa nostamme esiin pöytäkirjamateriaalista nousevia teemoja kuten oleskelu- ja työlupiin liittyvät ongelmat, oppilaitosten korkeat lukukausimaksut ja taloudelliset ongelmat sekä rasismi, työnantajien ja viranomaisten, etenkin poliisin, korruptio ja hyväksikäyttö.

Keskeisin elämään ja arjen toimintaan ja arjen turvattomuuteen vaikuttava kysymys oli oleskelu- ja turvapaikan saamiseen tai rekisteröitymiseen liittyvät ongelmat ja, kuten useimpien kohdalla, elämä paperittomana maahanmuuttajana. Paperittomaksi jääminen vaikuttaa suoraan maahanmuuttajien turvallisuuden tunteeseen, työ- ja asuntomarkkina-asemaan sekä palveluiden, kuten koulutuksen ja terveydenhoidon, saatavuuteen sekä oikeuksiin yhteiskunnassa. Nižni Novgorodissa ensin opiskellut kamerunilainen nainen kertoo pimeästä työstään sen jälkeen siivoojana Moskovassa ja kampaajana Mustanmeren rannikon matkailukohteessa.

\begin{abstract}
Menin Moskovaan ystävien luokse. 3 vuotta olin maassa laittomasti. Opiskeluiden päätyttyä viisumia ei ollut mahdollista uusia. [...] Venäjällä työskentelin siivoojana, pimeästi. Kesällä lähdin muiden afrikkalaisten kanssa rantaan työskentelemään, esimerkiksi tekemään afrikkalaisia kampauksia. (kamerunilainen nainen, rivi 378)
\end{abstract}

Kuten yllä, työmahdollisuudet paperittomana olivat usein satunnaisia, mikä takasi vain hyvin niukan ja epävarman toimeentulon. Työ oli yleensä mainosten jakamista, pimeän taksin ajamista, siivousta, tiskaamista, torimyyntiä ja afrikkalaisten kampausten laittamista. Se nivoutuu yhteen myös afrikkalaisten (ja muiden) maahanmuuttajien hyvin yleiseen hyväksikäyttöön työmarkkinoilla. Venäjällä puolitoista vuotta asunut kamerunilainen mies kertoi kokemuksista venäläisistä työnantajista sekä epävarmuudesta Venäjällä.

On huonoja muistoja Venäjältä. [...] Esimerkiksi jos pitää maksaa palkka kuun lopussa, vaikka 2000 ruplaa, niin työnantaja motivoi maksamalla pieniä summia, mutta ei koko palkkaa. (kamerunilainen mies, rivi 383)

Kongolainen mies, koulutukseltaan toimittaja, asui Venäjällä yli neljä vuotta valtaosin ilman oleskelu- tai työlupaa. Hän kertoi myös vaikeuksista työnantajien kanssa, mutta tuo esille myös paperittomuuden ja viranomaisten huonon kohtelun. Hän jäi lopulta ilman palkkaa virkavallalle tehdyistä avunpyynnöistä huolimatta.

Sitten siellä saattaa olla sellaisia tapauksia, että saa jostain töitä mutta työnantaja ei maksa, kun ei ole papereita. Minulle tämä tapahtui joulukuussa 2013, sain pienen työn rakennustyömaalta ja sieltä luvattiin, että 2 viikon päästä maksetaan palkka, mutta mitään palkkaa ei näkynyt. Sitten soitettiin poliisit, ja poliisit häätivät meidät pois sieltä ja sanoivat, että ette te mitään palkkaa saa. (kongolainen mies, rivi 1049) 
Kertomuksissa esiin nousevat poliisi- ja viranomaistoiminnan ongelmat eivät liity vain Venäjän maahanmuutto- ja pakolaispolitiikan kireyteen vaan erityisesti säännösten ja niiden täytäntöönpanon ristiriitoihin. Useat tutkijat ja kansalaisjärjestöt (katso Ivanova 2004; Litvinova 2016; Burtina, Korosteleva \& Simonov 2015) huomauttavat, että esimerkiksi Venäjän pakolaislainsäädäntö vastaa hyvin kansainvälisiä standardeja. Käytännössä viranomaiset toimivat kuitenkin mielivaltaisesti. Monissa tapauksissa hakemusta ei oteta edes käsittelyyn. Kuten Keski-Aasian työperäistä maahan muuttoa tutkinut Rano Turaeva (2019) huomauttaa, valtio kohtelee hakijoita ikään kuin heillä ei mitään oikeuksia olisikaan vaikka kaikki olisi kunnossa. Yllä mainittu kongolainen mies kertoo kertomuksissa usein toistuvasta poliisin toiminnan laittomuuksista ja korruptiosta:

Poliisi saattoi pidättää, jos ei ollut papereita, tai antaa sakot. Jos ei ollut papereita tai rahaa, he saattoivat ottaa puhelimen pois. 2014 linja alkoi olla aika tiukka ja kävin miettimään pitäisikö lähteä sieltäkin pois... Siellä lähiöissä jouduttiin maksamaan poliisille ns. voitelurahoja, näitä rahoja kerättiin yhteiseen kassaan kerran kuukaudessa. Rahoja maksettiin poliisille, jotta emme joutuisi vaikeuksiin. (kongolainen mies, rivi 1049)

Mahdollisuus korruptioon ja maahanmuuttajien hyväksikäyttöön Venäjällä lisääntyy oleskelu- tai työlupien tai asuinpaikan rekisteröitymisen ongelmien kanssa. Asuinpaikan rekisteröinnillä on edelleen tärkeä merkitys hallinnollisesti. Kaikkien tulee rekisteröityä asuinpaikkaan tai paikkaan, jossa vierailee. Sosiaalisten oikeuksien kuten koulutukseen tai terveydenhuoltoon pääsyn lisäksi se määrittelee pitkälti myös ihmisten liikkuvuutta ja pääsyä asuntomarkkinoille. Viime aikoina rekisteröinti on siirtynyt usein harmaille markkinoille (Nikiforova \& Brednikova 2018; Reeves 2013), jossa asuntojen omistajat ja työnantajat tarjoavat väärennettyjä rekisteröintejä, jolloin monet maahanmuuttajat rikkovat lakia tahattomasti (Muller 2018). Vuodet paperittomana Venäjällä tekivät kongolaisen miehelle myös asunto-ongelmat tutuiksi.

Siellä 25 vuotta Venäjällä asunut otti meitä maamiehiä vastaan ja siellä talossa oli kaksi huonetta ja keittiö. [...] Siellä kahdessa huoneessa asui 24 henkilöä ja maksoimme 4000 ruplaa per henkilö siitä vuokraa kuukaudessa. Tullessani oli kesä ja nukuin parvekkeella, koska sisätiloissa oli niin ahdasta. Maksimi aika oli 3-4 kk, kunnes poliisit tulevat kyselemään ketä siellä talossa on. Sen jälkeen kiertelin erilaisia taloja, joissa oli tuttuja majoittuneina, siellä viimeisimmässä talossa oli 17 henkilöä majoittuneena yhteen huoneeseen. [...] Koskaan siellä ei voinut kovin kauaa yhdessä paikassa asua. (kongolainen mies, rivi 1049)

Seuraava kamerunilainen mies puolestaan pohti vaihtoehtoja tilanteessa, jossa koulu lakkautettiin, asumiskulut kasvoivat ja opiskeluun perustuva oleskelulupa yhtäkkiä päättyi. Hän ei ollut tullut maahan väärennetyllä kutsulla tai kouluun, jota ei ollut olemassakaan, kuten osa Venäjälle saapuneista afrikkalaisista, vaan oikeasti opiskelemaan. Nyt hänen piti löytää asunto, vaikka suuri osa vuokranantajista ei halua itselleen ulkomaalaista vaan "slaavilaisen" vuokralaisen. (Ryumin 2018.) Nyt kun "raja oli auki", hän päätti mennä elämässä eteenpäin ja lähteä etsimään turvallisuutta Suomesta. 
Venäjälle saavuttuani kirjoittauduin yhteen kouluun, jossa aloitin tunnit. Kaksi kuukautta myöhemmin koulu sulki ovensa. Kun koulu laitettiin kiinni, niin kohtaloni oli edessä. Jotakin piti tehdä, jotta pystyi maksamaan laskut, vuokran ja muut, koska en asunut yliopistoasuntolassa. [...] Yhden toisen kamerunilaisen avustuksella hankin itselleni auton ja sen avulla yritin epävirallisesti harjoittaa taksitoimintaa. [...] Kun selvittelin sitä asiaa, sain luojan kiitos tietää, että Venäjän ja Suomen välinen raja oli avattu. (kamerunilainen mies, rivi 933)

\section{Järjestäytynyt rikollisuus ja inmiskauppa}

Arktisen reitin afrikkalaisten maastamuutto liittyi läheisesti kansainväliseen rikollisuuteen, erityisesti ihmissalakuljetukseen ja ihmiskauppaan. Turvapaikanhakijat käyttivät hyväksi kansainvälisiä ja paikallisia ihmissalakuljetukseen erikoistuneita verkostoja. Niiden avulla he saivat matkaan tarvittavat asiakirjat kuten passin, Venäjän viisumin ja Venäjältä poistumiseen tarvitun karkotuspäätöksen, vydvorenije. Kuten muualla maalimassa, myös osa arktisen reitin kautta Suomeen tulleista turvapaikanhakijoista päätyi Venäjälle ihmiskaupan ${ }^{7}$ uhreina. He olivat yksi selkeästi erottuva ryhmä, joiden kertomuksissa kasautuvat ongelmat vahvistivat kokemusta moniperusteisesta syrjinnästä ja äärimmäisestä turvattomuudesta maassa. Ihmiskaupan uhreiksi joutuneet olivat lähes poikkeuksetta naisia. He kokivat kertomustensa perusteella niin taloudelliseen asemaansa kuin sukupuoleensa kohdistuvaa hyväksikäyttöä. Yksi aineiston miehistä pakotettiin striptease-esiintyjäksi. Naisten kertomuksissa tuli esille selvästi seksuaaliseen hyväksikäyttöön liittyvän ihmiskaupan sukupuolittuneisuus ja siihen liittyvät erilaisset fyysisen ja psyykkisen väkivallan muodot (Gerassi 2018; UNODC 2018; Vähemmistövaltuutettu 2014).

Moni naisista oli lähtöisin köyhistä olosuhteista, työtön, matalasti koulutettu, orpo ja luuli tulevansa Venäjälle töihin tai opiskelemaan. Jotkut arvioivat, että heitä ei alun perin uhannut kotimaassaan mikään muu kuin yleinen näköalattomuus, mutta kotimaasta lähtöön liittyvät kertomukset liittyivät useimmiten pakkoavioliittoihin, seksuaaliseen hyväksikäyttöön tai vainoon, terrorismijärjestöjen toimintaan, taloudellisiin tai uskonnolliset riitoihin, pakkoprostituutioon tai oletettuun yhteydenpitoon "vääränlaisten" tahojen kuten ulkomaalaisten yritysten, järjestöjen tai asevoimien kanssa (mm. tulkit). Myös perheen kostoväkivaltaan liittyvät pelot olivat yleisiä. Nigerialainen nainen kertoi ihmiskaupan todellisuudesta Venäjällä samalla tavalla kuin asiaa on viimevuosina käsitelty kansainvälisessä mediassa (mm. Taub 2017; Kuronen 2019).

\footnotetext{
Naisella oli Venäjällä muita tyttöjä, jotka olivat sekaantuneet prostituutioon. Nainen vaati, että liityn heihin. Hän oli maksanut matkani Venäjälle ja jouduin työskentelemään hänelle, koska minulla ei ollut ystäviä joihin voisin turvautua. Sanoin naiselle, että en halua tehdä sitä työtä, että voin laittaa hiuksia. [...] Nigeriassa ei ole töitä. [...] Minulla ei ole ketään Nigeriassa. Äiti ja isä ovat kuolleet 2010. Minua ei uhkaa mikään Nigeriassa. (nigerialainen nainen, rivi 692)
}

Taubin (2017) arvion mukaan jopa tuhannet nigerialaiset nuoret joutuvat matkallaan Eurooppaan seksuaaliseen hyväksikäyttöön liittyvän ihmiskaupan uhreiksi. Tätä taustaa vasten aineistomme tarinat ihmiskaupasta eivät ole yllättäviä, vaan liittyvät laajempaan kansainväliseen ilmiöön. Uhrit oli houkuteltu Venäjälle lupauksilla "tavallisista" työpaikoista 
kampaamossa, ravintolassa tai ompelimossa. Todellisuudessa he joutuivat vuosia kestävään velkasuhteeseen ja pakkoprostituutioon. Heidän vaadittiin maksamaan salakuljettajalle matkajärjestelyihin liittyviä kuluja jopa 45000 USD.

Yksi nainen vei minut Venäjälle ja lupasi antaa minulle ompelijan työtä, mutta kun menin Venäjälle, hän pakotti minut prostituutioon. [...] Kun hakija kieltäytyi prostituutiosta, nainen pahoinpiteli hakijan ja otti tämän puhelimen pois. Ei voinut liikkua talosta vapaasti ulos. Hakija asui naisen talossa vuosia, (työskenteli prostituoituna v. 2012-2015), kunnes hän löysi eräänä päivänä passinsa ja pakeni. (nigerialainen nainen, rivi 694)

Eräs mies vei minut Venäjälle, tapasin hänet Nigeriassa. Hän sanoi, että kun osaan kampaajan työtä, voin tehdä sitä myös hänen salongissaan. [...] Hakijan oli työskenneltävä prostituoituna huolimatta vatsakivuista tai kuukautisista. Jos hakija voi huonosti, hänet pahoinpideltiin ja hänelle sanottiin, että jos hän ei tee työtä, velka ei lyhene. (nigerialainen nainen, rivi 754)

Kaiken kaikkiaan kertomuksista käy ilmi ihmiskaupan uhreiksi joutuneiden erittäin heikko fyysinen turvallisuus sekä kotimaassa että Venäjällä. Kertomuksissa toistui väkivallan uhka, prostituutioon liittyvät pelot vapaudenriistosta, raiskauksista ja kiristyksestä. Venäjällä parittajia pakeneminen ei välttämättä merkinnyt naisille turvaa, vaan myös maan sisäinenkin pakomatka saattoi olla vaarallinen. Pohjois-Venäjällä vietettyyn aikaan ja Suomen rajalle tuloon liittyvät kertomukset turvattomuudesta olivat kuitenkin vähäisiä. Siellä rikollisuus liittyi lähinnä turvapaikanhakijoiden lähtöprosessin valmistelemiseen. Useimmiten sattumalta tai ystävä- tai tuttavaverkostojen kautta löydetyt salakuljettajat järjestivät odotusajan majoituksen paikalliseen hotelliin ja hankkivat rajanylitykseen tarvittavan auton tai polkupyörän. Jos tulija oli käyttänyt matkajärjestelyissä matkatoimistoa tai esimerkiksi hotellin järjestämää taksia, hän ei välttämättä käsittänyt tätä salakuljetukseksi. Hinnat vaihtelivat matkan ja palvelun mukaan muutamasta sadasta eurosta tuhansiin euroihin henkilöltä.

Murmanskista Kantalahteen järjestin matkan itse matkatoimiston kautta ja matkan Kantalahdesta Suomeen hoidimme autolla. [...] Kantalahden hotellissa neuvottiin tekemään 5-6 hengen ryhmiä, jotka sitten ostaisivat yhdessä auton. Jokainen autossa olija maksoi 300 USD. Mukana piti olla aina joku, joka osaa ajaa autoa. Kuskin osuus oli 160 USD. [...] En tiedä mistä auto on ostettu, minä vain maksoin osani ja autonkuljettaja hoiti asian. Minun ei tarvinnut maksaa kuljettajalle. Minun mielestä salakuljettajaa ei ole käytetty. (kamerunilainen nainen, rivi 1122)

Hotellissa sanottiin, että joku auttaa pääsemään Suomeen ja että raja pitää ylittää autolla. Viikkoa myöhemmin Erik-niminen mies auttoi hakijaa ylittämään rajan. [...] Käytti salakuljettajaa. Antoi Erik-nimiselle miehelle muutaman päivän kuluttua (ei venäläinen) noin 800 USD, jotta pääsisi Suomeen. Hintaan kuului auto, hotelli ja bensakulut. (kongolainen mies, rivi 1062)

\section{Seksuaalivähemmistöt}

Seksuaalivähemmistöön $\left(\mathrm{LGBTI}^{8}\right)$ kuuluvat afrikkalaiset maahanmuuttajat muodostavat 
materiaalissamme toisen ryhmän, jonka kertomukset turvattomuudesta liittyvät selvästi moniperusteiseen syrjintään. Osa seksuaalisen suuntautuneisuutensa ilmaisseista turvapaikanhakijoista kertoi myös joutumisesta ihmiskaupan uhrina Venäjälle. Näiden ryhmien kotimaahan, asemaan Venäjällä ja maastamuuttoon liittyvät kertomukset ovat yleisesti ottaen hyvin samankaltaisia kuin muilla afrikkalaisilla maahaanmuuttajilla.

Useissa Afrikan maissa homoseksuaaliset suhteet on kriminalisoitu ja homoseksuaalisuudesta voi saada vankeutta tai jopa kuolemantuomion (Amnesty International 2018). Homoseksuaalisuuden rikollistaminen ja homoseksuaalisten turvapaikanhakijoiden hakijoiden kokema henkinen ja fyysinen väkivalta toistui aineistossamme. Kuten kamerunilaisten miesten ja nigerialaisen naisen esimerkeistä hyvin näkyy, nämä konkretisoituvat monille erilaisena uhkailuna ja väkivaltana sekä pelkona pidätyksistä, kidutuksesta tai kuolemasta.

Minun sukulaiseni uhkaa tappaa, koska olen homoseksuaali. (kamerunilainen mies, rivi 853)

Olen lesbo. Nigeriassa ihmiset ja perhe eivät hyväksyneet asiaa ja uhkailivat minua, siksi jouduin pakenemaan. (nigerialainen nainen, rivi 1101)

Meillä oli pieni homoseksuaalien yhdistys, mikä on Kamerunissa laitonta. Me kokoonnuttiin yksi lauantai jonkun luona. Kerran poliisi tuli yhtäkkiä paikalle ja minut pidätettiin ja vietiin selliin. Siellä muille kerrottiin heti, että olin homoseksuaali. Se oli painajaista. Vankien piti hoitaa siivoukset, kuivata virtsat ja siivota ulosteet ja kaikki tehtiin siinä $5 \mathrm{~m} 2$ tilassa. Siellä oli pahoinpitelyjä ja minua hakattiin ja eristettiin ja lyötiin nyrkillä. Jalkani turposi. En saanut verenpainelääkkeitäni. (kamerunilainen mies, rivi 990)

Homoseksuaaliset turvapaikanhakijat erittelivät lähdölle myös muita syitä kuin heidän seksuaalisuuteensa liittyvän syrjinnän. Ne liittyivät muun muassa yleiseen väkivallan uhkaan, perhe-, sukulais-/heimo- tai naapuririitoihin, terroristijärjestöjen, kuten Boko Haramin, uhkailuun ja pakkovärväykseen. Kuten muillekin afrikkalaisille turvapaikanhakijoille, Venäjä valikoitui muuttoliikkeen kohteeksi lähinnä siitä syytä, että sinne oli suhteellisen helppo saada viisumi, siellä odotettiin työllistymistä tai opiskelupaikkaa, kumppanin löytymistä tai turvapaikkaa.

Vaikka monet tutkijat ja ihmisoikeusjärjestöt kritisoivat Venäjän seksuaalivähemmistöjen tilannetta kovasanaisesti (kts. Human Rights Watch 2018; Kondakov 2014, 2017), maa näyttäytyy monien afrikkalaisten silmissä turvalliselta verrattuna kotimaahan. Onhan Venäjä osa Eurooppaa. Todellisuus on kuitenkin toinen. Pahoinpitelyt ovat yleisiä ja monet seksuaalivähemmistöön kuuluvat turvapaikanhakijat kokivat väkivaltaa ja joutuvat pelkäämään turvallisuutensa puolesta myös siellä. Kahden kamerunilaisen miehen ja yhden gambialaisen miehen kertomukset selventävät hyvin sitä, kuinka turvapaikanhakijat tulkitsivat ihonväriin liittyvän rasistisen väkivallan ja seksuaalisuuteen perustuvaan väkivallan yhteyden.

Saavuin erään kerran yökerhosta ystäväni kanssa ja sitten sieltä tuli kohti ihmisiä, kun huomattiin, että olin musta ja siitä syystä meitä lähestyttiin. Kun he olivat tarpeeksi lähellä, he näkivät että kaksi miestä on yhdessä ja näkivät että olemme vielä homoja. Siitä tuli iso tappelu, jota en unohda koskaan, ja otsassani on arpi, joka on tullut puukosta. 
Hakija pahoinpideltiin Venäjällä kahdesti, toisella kerralla henkihieveriin. [...] Selvisin toisesta hyökkäyksestä, mutta se oli katastrofi. [...] Venäjälläkään ei pidetä homoseksuaaleista. Sen lisäksi olen vielä ulkomaalainen ja musta (kamerunilainen mies, rivi 541)

Seksuaalivähemmistöihin kuuluvien afrikkalaisten kertomuksissa moniperusteinen ihonväriin ja seksuaalisuuteen kohdistuva syrjintä oli tavallista. Svetlana Boltovskayan (2010, 94; kts myös Nassor 2004) mukaan rodullisesti motivoitunut väkivalta on Venäjällä niin yleistä, että siitä on maan afrikkalaisten keskuudessa tullut eräänlainen jaettu kokemus. Lisäksi Venäjä on erittäin homofobinen. LGBTI-turvapaikanhakijoiden kertomuksissa haukkuminen kytkeytyykin läheisesti rasistisesti ja homofobisesti motivoituneeseen viharikollisuuteen. ${ }^{9}$ Heidän arjen turvattomuutensa liittyi ensisijaisesti ihonväriin ja homoseksuaalisuuden ilmaisemiseen julkisilla paikoilla. He olivat alttiita rasistiselle herjaukselle ja kokivat fyysistä turvattomuutta toistuvasti liikkuessaan tai työskennellessään kadulla. Aineistossamme lehdenjakajina työskennelleet gambialaiset miehet kiteyttivät rasismin ja poliisin välinpitämättömyyden vaikutuksen arkeen.

\begin{abstract}
Venäjä ei vastannut kuvaa, joka minulla oli Venäjästä. Siellä oli myös paljon rasisteja. Kaksi miestä myös hyökkäsi kimppuuni. Tästä näkyy jäljet. He halusivat tappaa minut. Se oli kesäkuussa muistaakseni. [...] Hakija ei tuonut Venäjällä esiin seksuaalista suuntautumistaan, koska tiesi että siellä suhtaudutaan negatiivisesti homoseksuaaleihin. Ihon väri oli syy hyökkäykseen. (gambialainen mies, rivi 136)
\end{abstract}

$[\mathrm{H}]$ alusin hakea turvapaikkaa, mutta en löytänyt paikkaa, josta sitä voisi hakea. Tiedustelin asiaa poliisilta, ja he vaan naureskelivat koko jutulle. Poliisit sanoivat, ettei heillä ole käsitystä turvapaikasta, ja nauroivat ja pilkkasivat minua. [...] Oli rasisteja siellä, ihmiset solvasivat ja pilkkasivat minua, ja aina kun olin töissä, he haukkuivat minua. Elämä siellä oli liian rankkaa minulle. (gambialainen mies, rivi 872)

Ihonväriään he eivät voi millään tavalla piilottaa, mutta seksuaalisuuden tuominen esiin tai, kuten materiaalimme muiden afrikkalaisten maahanmuuttajien osalta, paperittomuus, työnantajien hyväksikäyttö, viranomaisten korruptio tai joutuminen tekemisiin alamaailman kanssa voivat johtaa vaikeuksiin ja lisätä arjen turvattomuutta myös Venäjällä.

\title{
Turvallisuutta etsimässä
}

Tässä artikkelissa olemme tarkastelleet Venäjältä Suomeen ja Euroopan Unioniin suuntautuneita arktisen reitin tapahtumia Venäjällä asuneiden afrikkalaisten maahanmuuttajien ja turvallisuuden näkökulmasta. Suomalaista julkisuudessa käytyä keskustelua ja turvapaikanhakijoiden kertomuksia analysoitaessa on selvää, että Venäjä ja muuttoliikkeeseen liittyvä turvallisuus saa monenlaisia merkityksiä. Siinä, missä viranomaiset olivat välittömissä ratkaisuissa kiinnostuneita rajojen hallinnasta ja hallitsemattoman maahanmuuton ehkäisystä, Venäjällä asuneiden maahanmuuttajien näkökulmasta kysymys oli heidän maassa kohtaamastaan arjen turvattomuudesta.

Afrikkalainen Venäjä on monimuotoinen ja muuttunut vuosikymmenten saatossa. Neu- 
vostoliitossa koulutetut eri Afrikan maista tulevan diasporan jäsenet ovat löytäneet paikkansa venäläisessä yhteiskunnassa. Sen sijaan 1990-luvulta lähtien Venäjälle suunnanneet pakolaiset ja taloudelliset siirtolaiset, sekä osa opiskelijoistakin, hakevat Venäjältä joko taloudellista turvaa ja tulevaisuutta, tai fyysistä turvaa pakolaisina. Arktisen reitin afrikkalaiset maahanmuuttajat kuuluivat näihin varsin heterogeenisiin maahanmuuttajiin lähinnä Saharan alueelta ja sen eteläpuolisista Afrikan maista. Heille Venäjä oli päämäärä, koska se on mielikuvissa osa Eurooppaa ja lähellä Euroopan Unionia. Sinne on myös mahdollista saada viisumi suoraan konsulaatista tai erilaisten matkanjärjestäjien tai agenttien avustamana.

Vaikka maahanmuuttajien odotukset Venäjää kohtaan olivat suuret, niin monet todellisuudessa päätyivät maassa epävakaaseen elämäntilanteeseen ja päätökseen lähteä maasta. Muuttopäätösten taustalla vaikuttivat monet arjen turvattomuuteen liittyvät ongelmat: oleskelu- ja työluvan sekä asuinpaikan rekisteröinnin vaikeudet, taloudelliset ongelmat, venäläisen yhteiskunnan rasismi, hyväksikäyttö työmarkkinoilla sekä viranomaisten korruptio ja välinpitämättömyys. Monille afrikkalaisille maahanmuuttajille Venäjä ei ollut turvallinen. Erityisen haavoittuvia ryhmiä olivat seksuaalivähemmistöjen edustajat ja ihmiskaupan uhriksi joutuneet naiset, jotka kohtasivat matkalla usein moniperusteista syrjintää. Yleisen arjen turvattomuuden lisäksi monet heistä kokivat erilaista henkistä ja fyysistä väkivaltaa.

Koska Venäjä on yksi kansainvälisten muuttoliikkeiden keskuksista, turvallisuusympäristön muutokset maailmalla sekä Venäjän maahanmuuttopolitiikka voivat heijastua arktiseen reittiin ja Suomeen nopeastikin. Uutiset ja huhut "avoimesta rajasta" pohjoisessa konkretisoivat Venäjällä asuneiden maahanmuuttajien muuttopäätöksen ja syystä tai toisesta Venäjän viranomaiset eivät pyrkineet estämään arktisen reitin liikennettä ennen helmikuun loppua 2016. Näin maahanmuuttajien arjen turvattomuus siirtyi Suomen rajalle kysymykseksi valtion rajaturvallisuudesta.

\section{Viitteet}

1 Artikkelin ovat mahdollistaneet Strategisen tutkimuksen neuvoston rahoittama "Globaalin turvallisuuden monikerroksiset rajat" (GLASE) -hanke (nro. 303480) sekä Suomen Akatemian hankkeet 308914 and 309602.

2 Moniperusteinen syrjintä on intersektionaalisen feministisen teorian tunnistama ilmiö, jossa syrjintä kohdistuu useampaan yksilön ominaisuuteen kuten sukupuoleen, seksuaalisuuteen, luokkaan, ihonväriin, ikään ja kyvykkyyteen aiheuttaen yksilöllisiä syrjimiskokemuksia. (Hill \& Bilge 2016, 12)

3 Piia Koivusen $(2014,74-76)$ mukaan nuorisofestivaali muistetaan ennen kaikkea sukupuolimoraalin vapautumisen seurauksista ja niin sanotuista festivaalilapsista. Termi deti festivalija (tai joskus festivalnyje deti) viittaa yhdeksän kuukautta festivaalin jälkeen syntyneisiin aviottomiin lapsiin. Todellisuudessa "suklaalapsia" pidettiin häpeällisenä neuvostoliittolaiselle moraalijärjestelmälle ja lapset synnyttäneille tytölle itselleen. Suuri osa lapsista syntyi maassa opiskelleiden afrikkalaisten miesten ja venäläisten naisten avioliitoista.

4 Patrice Lumumban yliopisto tunnetaan myös Venäjän kansojen ystävyyden yliopistona (Peoples' Friendship University of Russia) ja sittemmin RUDN-yliopistona. Katso: http://www.rudn.ru

5 Asuinpaikan rekisteröiminen jäljitetään usein Neuvostoliiton asumislupaan propiska, jonka tarkoituksena oli säädellä ihmisten liikkumista Neuvostoliiton sisällä (Nikiforova, Brednikova 2018; Reeves 2013; Nozhenko 2010). Propiska kiinnitti henkilön tiettyyn asuinpaikkaan ja säänteli hänen pääsynsä työmarkkinoille ja palveluihin. Virallisesti asumislupa poistettiin käytöstä vuonna 1993, 
mutta se tuli tavallaan uudelleen rekisteröitymisenä, registratsija.

6 Ennen ensimmäistä turvapaikkapäätöstä turvapaikanhakija kävi hakuprosessissa läpi kaksi vaihetta, tuolloin vielä poliisin tai rajavartiolaitoksen tekemän turvapaikkakuulustelun ja maahanmuuttoviraston tekemän turvapaikkapuhuttelun.

7 Finlexin (2006) suomennoksen mukaan ihmiskauppa "tarkoittaa hyväksikäyttötarkoituksessa tapahtuvaa henkilöiden värväystä, kuljettamista, siirtämistä, kätkemistä tai vastaanottamista voimankäytöllä uhkaamisen tai voimankäytön tai muun pakottamisen, sieppauksen, petoksen, harhaanjohtamisen, vallan väärinkäytön tai haavoittuvan aseman hyödyntämisen avulla, taikka toista henkilöä vallassaan pitävän henkilön suostumuksen saamiseksi annetun tai vastaanotetun maksun tai edun avulla. Hyväksikäytöksi katsotaan vähintään toisen hyväksikäyttö prostituutiotarkoituksessa tai muut seksuaalisen hyväksikäytön muodot, pakkotyö tai pakollinen palvelu, orjuus tai muu orjuuden kaltainen käytäntö, orjuuden kaltaiset olot tai elinten poistaminen.” Perustuu YK:n vuoden 2009 Palermon yleissopimuksen lisäpöytäkirjaan.

8 LGBTI-turvapaikanhakijat-käsite viittaa UNHCR:n Ohjekirjan (UNHCR 2012) määritelmään henkilöistä (lesbo, homo, biseksuaali, muunsukupuolinen ja intersukupuolinen), jotka kokevat vainoa heidän seksuaalisen suuntauksensa tai kuvitellun seksuaalisen suuntauksensa vuoksi ja/tai sukupuoliidentiteettinsä takia. Heitä ei välttämättä tunnusteta turvapaikanhankijoiksi Venäjän federaatiossa.

9 Viharikoksella on ennakkoluuloihin perustuva motivaatio, ja tekijä valikoi uhrinsa jonkin kollektiivisen erityispiirteen takia, kuten esimerkiksi "rodun", kielen, uskonnon, etnisyyden tai kansallisuuden vuoksi (OSCE/ODIHR 2009). Seksuaalivähemmistöjen etujärjestö ILGA Europe erittelee LGBTI-fobisen viharikollisuuden väkivallaksi ja aggressioksi, joka kohdistuu LGBTI-ihmisiin heidän kuvitellun tai tosiasiallisen seksuaalisen suuntauksen, sukupuoli-identiteetin tai sukupuolisten ominaisuuksien perusteella (ILGA 2018). Viharikollisuus toimii artikkelissamme enemmän käsitteellisenä kuin juridisena terminä.

\section{Lähteet}

Amnesty International UK (2018), Mapping anti-gay laws in Africa. 31.5. https://www.amnesty.org. uk/lgbti-lgbt-gay-human-rights-law-africa-uganda-kenya-nigeria-cameroon (Tarkistettu 13.4.2019).

Blakely, Allison (2007), African Imprints on Russia: An Historical Overview. - Africa in Russia: Russia in Africa: Three Centuries of Encounters. Ed. Maxim Matusevich. Toronto: Africa World Press, 37-59.

Boltovskaya, Svetlana (2010), African Communities in Moscow and St. Petersburg: Issues of Inclusion and Exclusion. - Cultural Diversity in Russian Cities: The Urban Landscape in the Post-Soviet Era. Ed. Cordula Gdaniec. London: Berghahn Books, 94-114.

Bondarenko, Dmitri (2018), Haastattelu. Venäjän tiedeakatemian Afrikka-instituutti, Moskova. 10.12.

Bondarenko, Dmitri, Demintseva, Ekaterina, Usacheva, Veronica \& Zelenova, Daria (2014), African Entrepreneurs in Moscow: How They Did It Their Way. - Urban Anthropology and Studies of Cultural Systems and World Economic Development 43:1-3, 205-254.

Burtina, Elena, Korosteleva, Ekaterina \& Simonov, Vladislav (2015), Rossija kak strana ubežištša: Doklad ob ispolnenii Rossijskoi Federatsiei konventsii o statuse bežentsev 1951 goda. Moskva: Komitet graždanskoje sodeistvije, https://memohrc.org/sites/default/files/rossiya_kak_strana_ ubezhishcha source.pdf (Tarkistettu 12.4.2019).

C.A.S.E Collective (2006), Critical Approaches to Security in Europe: A Networked Manifesto. Security Dialogue 37: 4, 443-487, https://doi:10.1177/0967010606073085

Cocks, Frances M. Somres (2007), The African Origins of Alexander Pushkin. - Africa in Russia: 
Russia in Africa: Three Centuries of Encounters. Ed. Maxim Matusevich. Toronto: Africa World Press. 13-35.

Crawley, Heaven, Düvell, Franck, Jones, Katharine, McMahon, Simon \& Nando, Sigona (2018), Unvravelling Europe's 'Migration Crisis': Journeys over land and sea. Bristol: Policy Press.

Ekholm, Thea (2018), Kymmeniä kisaturisteja yritti tulla Venäjältä Viroon pelkällä MM-kisapassilla, 23.7. https://www.tallinna24.ee/artikkeli/688947-kymmenia-kisaturisteja-yritti-tulla-venajaltaviroon-pelkalla-mm-kisapassilla (Tarkistettu 15.4.2019)

Finlex (2006), Kansainvälisen järjestäytyneen rikollisuuden vastaisen Yhdistyneiden Kansakuntien yleissopimuksen lisäpöytäkirja ihmiskaupan, erityisesti naisten ja lasten kaupan ehkäisemisestä, torjumisesta ja rankaisemisesta. https://www.finlex.fi/fi/sopimukset/sopsteksti/2006/20060071/20060071_2 (Tarkistettu 13.42019)

Gerassi, Lara (2018), Sex trafficking and commercial sexual exploitation: Prevention, advocacy, and trauma-informed practice. New York: Springer Publishing Company.

GLASE (2016), Globaalin turvallisuuden monikerroksiset rajat: Tilannekuvaraportti 2016. Strateginen tutkimus, Suomen Akatemia. https://www.aka.fi/globalassets/33stn/tilannekuvaraportit/stn2016hankkeet/glase tilannekuvaraportti2.pdf (Tarkistettu 20.8.2019)

Heusala, Anna-Liisa (2012), Kokonaisturvallisuus ja inhimillinen turvallisuus yhteiskuntatieteellisessä tutkimuksessa - Tiede ja ase 69, https://journal.fi/ta/article/view/7469 (Tarkistettu 26.8.2019)

Hill, C. P., \& Bilge, S. (2016), Intersectionality. Cambridge, UK; Malden, MA: Polity Press.

Holland, M. (2018), Stories for Asylum: Narrative and Credibility in the United States' Political Asylum Application. - Refuge 34:2, 85-93, https://doi.org/10.7202/1055579ar (Tarkistettu 3.10.2019).

Human Rights Watch (2018), No Support: Russia's "Gay Propaganda" Law Imperils LGBT Youth. December 2018. https://www.hrw.org/sites/default/files/report_pdf/russia1218_web2.pdf(Tarkistettu 10.4.2019)

Ivakhniouk, Irina (2004), Illegal Migration: Russia. - European Security 13:1-2, 35-53, https:// doi:10.1080/09662830490484791

Ivanova, Tatjana (2004), Est li buduštšee v Rossii y afganskih bežentsev? - Otetšestvennyje zapiski 20:5, http://www.strana-oz.ru/2004/5/est-li-budushchee-v-rossii-u-afganskih-bezhencev (Tarkistettu 2.9.2019)

ILGA-Europe (2018), Hate crime \& hate speech. https://www.ilga-europe.org/what-we-do/ouradvocacy-work/hate-crime-hate-speech (Tarkistettu 8.4.2019)

Katsakioris, Constantin (2017), The Lumumba University in Moscow. Higher Education for a SovietThird World Alliance 1960-1990. Online lecture. New York, NYU Jordan Center, 21.4.2017, https:// www.youtube.com/watch? $\mathrm{v}=62 \mathrm{xy}$ YdpfcFM (Tarkistettu 12.4.2019).

Koivunen, Pia (2014), Nuorisofestivaali Venäjän kulttuuridiplomatian välineenä. - Idäntutkimus $21: 1,85-89$.

Kondakov, Alexander (2014), The Silenced Citizens of Russia: Exclusion of Non-heterosexual Subjects from Rights-Based Citizenship. - Social \& Legal Studies 23:2, 151-174, https:// doi: $10.1177 / 0964663913505315$

Kondakov, Aleksandr (2017), Prestuplenija na potšve nenavisti protiv LGBT v Rossii: ottšet. Tsentr nezavisimyh sotsiologitšeskih issledovanii. Sankt Peterburg: Renome.

Kunichoff, Yana (2018a), Scammed Nigerians Stranded in Russia Amid World Cup Trafficking Fears, 18.7. https://www.themoscowtimes.com/2018/07/18/amid-world-cup-trafficking-fears-scammednigerians-stranded-in-russia-a62285 (Tarkistettu 12.4.2019).

Kunichoff, Yana (2018b), More Than 100 Fan ID Holders Are Seeking Asylum in Russia, Aid Group Says, - The Moscow Times, 20.8. https://www.themoscowtimes.com/2018/08/20/more-than100-fan-id-holders-seek-asylum-russia-human-rights-group-says-a62582 (Tarkistettu 12.4.2019).

Kuronen, Antti (2019), Ulkolinja: Naiskaupan ytimessä. YLE 4.2. https://areena.yle.fi/1-4518040 (Tarkistettu 10.4.2019)

Litvinova, Daria (2016), Russia's Refugees: They Picked the Wrong Country, - The Moscow Times 14.10. https://themoscowtimes.com/articles/they-picked-the-wrong-country-55702 (Tarkistettu 8.4.2019).

Matusevich, Maxim (2012), Expanding the boundaries of the Black Atlantic: African Students as Soviet Moderns. - Ab Imperio 2/2012, 325-350, https://doi:10.1353/imp.2012.0060

Matusevich, Maxim (2009), Probing the Limits of Internationalism: African Students Confront Soviet Ritual. - Anthropology of East Europe Review 27:2, 19-39. https://scholarworks.iu.edu/journals/ 
index.php/aeer/article/view/166/259

Moe, Arild, and Lars Rowe (2016), Asylstrømmen fra Russland til Norge i 2015: Bevisst russisk politikk? - Nordisk Østforum 30:2, 80-97, https://doi.org/10.17585/nof.v30.432

Muller, Nicholas (2018), Russia: New migrant registration rules threaten tenuous livelihoods. - Eurasianet, 17.7., https://eurasianet.org/russia-new-migrant-registration-rules-threaten-tenuous-livelihoods (Tarkistettu 20.8.2019).

Nerg, Päivi \& Järvenkylä, Nina (2019), Tiukka Paikka. Jyväskylä: Docendo.

Nikiforova, Elena \& Brednikova, Olga (2018), On Labor Migration to Russia: Central Asian Migrants and Migrant Families in the Matrix of Russia's Bordering Policies. - Political Geography 66, 142-150, https://doi:10.1016/j.polgeo.2018.04.006

Nozhenko, Maria (2010), Focus Migration, country profiles: Russian Federation. Hamburg Institute of International Economics, 20.7. http://focus-migration.hwwi.de/RussianFederation.6337.0.html?\&L=1 (Tarkistettu 5.4.2019).

OSCE /ODIHR (2009), Hate Crime Laws. A Practical Guide. Warsaw: Polygrafus Andrzej Adamiak.

Paananen, Arja (2018), Venäjä pidätti Suomeen pyrkineitä "jalkapallofaneja" - yllättävistä maista tullut paljon MM-fanikorttihakemuksia,-Ilta-Sanomat 21.6. https://www.is.fi/kotimaa/art2000005728314.html?cs=email (Tarkistettu 12.4.2019)

Patterson, Molly \& Renwick Monroe, Kristen (1998), Narrative in Political Science. - Annual Review of Political Science 1, 315-331, https://doi.org/10.1146/annurev.polisci.1.1.315

Piipponen, Minna, Joni Virkkunen (2019), The Remigration of Afghan Immigrants from Russia. Nationalities Papers (forthcoming)

Puumala, Eeva, Ristimäki, Hanna-Leena \& Ylikomi, Riitta (2019), Kokemus, kertominen ja tieto turvapaikkamenettelyssä. - Turvapaikanhaku ja pakolaisuus Suomessa. Toim. Lyytinen Eveliina. Turku: Siirtolaisuusinstituutti, 137-159.

Quist-Adade, Charles (2007), The African Russians: Children of the Cold War. - Africa in Russia: Russia in Africa: Three Centuries of Encounters. Ed. Maxim Matusevich. Toronto: Africa World Press, 153-173.

Rajavartiolaitos (2016a), Katsaus Rajavartiolaitoksen toimintaan vuonna 2015, 8.1. https://www.raja. fi/tietoa/tiedotteet/1/0/katsaus_rajavartiolaitoksen_toimintaan_vuonna_2015_64725 (Tarkistettu 30.8.2019).

Rajavartiolaitos (2016b), Rajavartiolaitoksen tiedote 3.3.2016, 4.9. https://www.raja.fi/tietoa/tiedotteet/1/0/rajavartiolaitoksen_tiedote_3_3_2016_66280 (Tarkistettu 30.8.2019).

Reeves, Madeleine (2013), Clean fake: Authenticating documents and persons in migrant Moscow. - American Anthropologist 40: 3, 508-524, https://doi:10.1111/amet.12036

Round, John \& Kuznetsova, Irina (2016), Necropolitics and the Migrant as a Political Subject of Disgust: The Precarious Everyday of Russia's Labour Migrants. - Critical Sociology 42:7-8, 1017-1034, https://doi:10.1177/0896920516645934

Ryazantsev, Sergey (2016), Labour Migration from Central Asia to Russia in the Context of the Economic Crisis. Valdai Papers \#55, Valdai Discussion Club, http://valdaiclub.com/files/11628/ (Tarkistettu 5.4.2019).

Ryumin, Alexander (2018), One Man's Fight Against Slavs-Only Apartment Rentals in Moscow. The Moscow Times, 27 February, https://themoscowtimes.com/articles/one-man-pushes-back-againstslavs-only-renting-discrimination-60632 (Tarkistettu 12.4.2019).

Tanttu, Tarja (2017), "Sitten uskaltaa kertoo omista asioista enemmän" Maahanmuuttaja-asiakkaiden työvoimaneuvojan käsityksiä luottamuksen rakentamisesta asiointikeskustelussa. - Prologi. Puheviestinnän vuosikirja 2017: 24-41.

TASS (2019), Boleje 5 tys. prijehavših na TšM-2018 inostrantsev vse ještše nelegalno nahodjatsja v Rossii. 25.1.https://tass.ru/obschestvo/6040387?utm_source=twitter.com\&utm_medium=social\&utm_ campaign $=$ smm_social_share (Tarkistettu 12.4.2019).

Taub, Ben (2017), The Desperate Journey of a Trafficked Girl, - New Yorker 3.4. https://www.newyorker.com/magazine/2017/04/10/the-desperate-journey-of-a-trafficked-girl (5.4.2019).

Tuomi, Jouni \& Sarajärvi, Anneli (2018), Laadullinen tutkimus ja sisällön analyysi. Helsinki: Tammi. Turaeva, Rano (2019), Imagined mosque communities in Russia: Central Asian

migrants in Moscow. - Asian Ethnicity 20:2, 131-147, https://doi.org/10.1080/14631369.2018.1525529

UNHCR (2012), Guidelines on International Protection No. 9: Claims to Refugee Status based on Sexual Orientation and/or Gender Identity within the context of Article 1A(2) of the 1951 Con- 
vention and/or its 1967 Protocol relating to the Status of Refugees. HCR/GIP/12/09. https://www. unhcr.org/50ae466f9.pdf (Tarkistettu 8.4.2019)

UNODC (2018), Global Report on Trafficking in Persons. United Nations publication, Sales No. E.19.IV.2.

Virkkunen, Joni (2018), Borders, Polarisations, and Activisms: Uncovering the Migration-Security Nexus in Finland during the 2015-2016. - How to deal with refugees? Europe as a Continent of Dreams. Ed. Gerhard Besier, Katarzyna Stokłosa. Berlin: LIT Verlag, 225-244.

Vähemmistövaltuutettu (2014), Kansallisen ihmiskaupparaportoijan raportti eduskunnalle 2014. Helsinki: Grano.

Želtov, A. (2012), Rossija i Afrika - istorija i sovremennost. Vestnik Sankt-Peterburskogo universiteta 13:4, 3-13. 